\title{
The Application of Schema Theory to EFL Reading Teaching
}

\author{
Yan Zhang \\ Department of Foreign Language, Jiujiang University, Jiangxi, China \\ ZhangYan@yeah.net
}

\begin{abstract}
Keywords: Schema theory, Teaching process, College English reading, Reading comprehension, Examination
\end{abstract}

\begin{abstract}
This study was conducted under the guidance of the schema theory and based on the textbook (New Horizon College English (Second Edition) Book 1). The author investigated the effectiveness of using schema theory in the teaching of college English reading with a combination of descriptive qualitative and quantitative methods: a questionnaire, an experimental teaching practice and an interview after the experiment. The experiment lasted for sixteen weeks and it was conducted upon 80 freshmen in two groups with different levels of English proficiency, and each group consisted of two level-based classes. For formal schema, to analyze the different writing styles and features of different reading material, so as to help students to become familiar with the structure, the organization and the main idea of the text and to accumulate rich formal schemata.
\end{abstract}

\section{Introduction}

The importance of English reading in college English teaching has made the application of effective teaching method to improve students' reading comprehension become the teachers' great concern for a long time. Since 1970s, the linguists at home and abroad have put forward the idea of applying schema theory in reading process. They believe that it can effectively improve knowledge and their students' reading comprehension to integrate readers' background prior experience with the reading material.

College English Syllabus states that college English aims at developing a comparatively high level of reading comprehension and an appropriate level of ability in listening, speaking and writing and translation. Obviously, reading plays a very important part in English learning. It is an important approach for students to acquire foreign language knowledge, and it is the basis for students to improve their four other important skills-listening, speaking writing and translation abilities- in language acquisition [1].

Schema theory originated in the field of psychology, which appeared in the study of mental organization for storing and retrieving the existing knowledge while brain dealing with the new information. Most researchers considered that schema is of great significance and has great impact to reading comprehension. It is considered that reading comprehension is a process of integrating readers' schematic knowledge with the text itself and the schema theory can help readers not only to understand each individual word and sentence, but also to comprehend the main idea of the text and the author's intention [2]. Therefore, it is necessary for English teachers to know how to teach reading course effectively and help students to improve their reading ability [3].

Over the past years, researchers conducted many studies on reading comprehension in order to find a reading model. Teachers also try to use different teaching methods in reading teaching, yet the results are not fully up to their expectations [4]. This thesis will review the research status of schema theory, illustrate the nature of reading comprehension, introduce the applications of schema-oriented teaching method in college English reading classes, investigate the effects the schema theory has on reading comprehension and finally analyze the schema theory's implication for college English reading teaching.

As Gough (1972) has pointed out: reading process starts from letters, to words, to sentences, and finally to meaning [5]. This reading method is widely used in China and has an important position in many teachers' mind during teaching. Teachers emphasize more on language knowledge, words and 
semantic decoding, which seriously limits the development of students' reading abilities. Most of the students think the focus and center of reading is to recognize new words and phrases, neglecting to grasp the intended ideas that the authors want to express in the texts. Teachers did not pay attention to students' understanding of cultural knowledge of the target language and, ignore the context, culture, background and so on, and therefore, they cannot motivate students' enthusiasm in reading and improve students' reading comprehension. As a result, reading classes are teacher-centered, and students become passive learners. Due to the importance of reading and the present unsatisfactory situation of reading teaching mentioned above, researchers believe that it's reasonable to recommend reading practice based on the schema theory because it not only emphasizes the training of complete understanding of the text but also stresses the training of students to take part in an interactive process in reading.

\section{The Process of Experiment Design}

According to the schema theory, reading is an interactive process between reader and the reading material. However, most of the freshmen are taught through the traditional teaching method before they entering college, so it is necessary for teacher to stimulate students of the experimental class to be active in learning each text at the very beginning of the experimental teaching. Compared with the mature readers, the students lacked of reading strategies and skills and they will encounter a lot of difficulties while leaning. So the teacher should encourage and train them to play an active role in the reading process. At the same time, the teacher should also help students to make full preparation to the reading task and train them to consciously use the schema strategies. While the subjects build and activate their schemata in the reading process, teacher's assisting role cannot be neglected. And the reading material used in the experiment should be carefully selected based on the students' English proficiency, so that the texts can arouse students' great interest, activate their existing schemata and help them to build new schemata. The author worked out a teaching plan based on the situation that many students could not use their background knowledge appropriately in reading process. The reading teaching plan is shown in Fig. 1.

\begin{tabular}{|l|l|}
\hline the control class & the experiment class \\
\hline the traditional teaching method & schema strategy training \\
\hline $\begin{array}{l}\text { 1. to explain the vocabulary and the } \\
\text { important sentences }\end{array}$ & $\begin{array}{l}\text { 1. to explain the key words } \\
\text { 2. to guide students to do the pre-reading activities and } \\
\text { to translate the text sentence by } \\
\text { sentence }\end{array}$ \\
$\begin{array}{l}\text { 3. guide students to understand the passage according to } \\
\text { both the detailed information and their existing } \\
\text { 4. do not introduce reading } \\
\text { strategies consciously }\end{array}$ & $\begin{array}{l}\text { k. introduce some reading strategies, such as prediction, } \\
\text { skimming and scanning and looking for the key words } \\
\text { 5. recite the passage and write the example composition } \\
\text { after reading }\end{array}$ \\
\hline
\end{tabular}

Fig. 1 The reading teaching plan

Students' active participation is the most effective way to improve their English reading ability. English reading requires students' self control ability, which means that students need to focus their mind on the English words of the reading material. For those students with low English proficiency and weak willpower, if they encounter a little difficulty, the reading process might be interrupted. This is the phenomenon we often find in the reading process "some students' eyes move, but their brain does not work". Based on this phenomenon, the author put forward the models of schema strategy training:1) Structure (formal) schema training;2) Background information (content) schema training;3) Activation of the schemata in the process of problem-solving.

Students participate in the questionnaire survey come from the four classes taught by the author. The author took use of the class time to carry on the questionnaire survey before the experiment. Before the questionnaire papers are distributed to the students, and the author explained the purpose of the questionnaire survey and asked them to truthfully answer the questions. All the students seriously answered these questions under the guidance of the author. In the two experimental classes 
and the two control classes, 80 questionnaire papers are handed out respectively, and all the 80 effective questionnaire papers are collected back from the four classes.

The pre-test was carried out for the control class and the experimental class in group A and group B in class individually in April, 2013. The pre-test lasted for 45 minutes. The author supervised the process. The post-test was carried out for the control class and experimental class in group A and group B individually in July, 2013, after students' learning of the whole textbook. The post-test lasted for 45 minutes and the author supervised the test process, too. The author marked all the test papers by herself after each test. The raw scores of the pre-test and the post-test of the four classes were listed in a table. The author analyzed the data of the scores of the pre-test and the post-test through SPSS 19.0.

The author conducted the interviews in her office. The author selected four students from each experimental class, who were interviewed with the five questions first. It lasted 40 minutes. The next day, the author also selected four students from each control class who were interviewed with the five questions, too. It also lasted for 40 minutes. The author recorded all the conversations on site using a voice recorder. The comments and the main ideas of the answers given by the student representatives were written down by the author later. In chapter four, the author analyzed their words on the basis of her own perspective and understanding.

\section{Results of the Tests and Analysis}

Before the experiment, the pre-test is conducted in the two groups of classes, which was used to evaluate whether there was any difference between the control classes and the experimental classes. The Fig.2-Fig.5 is the results of the four classes based on the pre-test scores.

\begin{tabular}{llllll}
\hline Variance & Num. & Mini. score & Max. score & Average. score & $>=60$ scores \\
\hline Control class & 20 & 45 & 80 & 61.25 & 12 \\
Experimental class & 20 & 45 & 85 & 61.75 & 12 \\
\hline
\end{tabular}

Fig.2 Scores Statistics of Pre-test of Level-based Class Band Two

\begin{tabular}{llllll}
\hline Variance & Num. & Mini. score & Max. score & Average. score & $>=60$ scores \\
\hline Control class & 20 & 35 & 75 & 55.25 & 9 \\
Experimental class & 20 & 35 & 75 & 54.75 & 7 \\
\hline
\end{tabular}

Fig.3 Two Scores Statistics of Pre-test of Level-based Class Band One

\begin{tabular}{llllll}
\hline Variance & Num. & Mini. score & Max. score & Average. score & $>=60$ scores \\
\hline Control class & 20 & 50 & 85 & 64.75 & 15 \\
Experimental class & 20 & 50 & 90 & 70.25 & 17 \\
\hline
\end{tabular}

Fig.4 Scores Statistics of Post-test of Level-based Class Band Two

\begin{tabular}{llllll}
\hline Variance & Num. & Mini. score & Max. score & Average. score & $>=60$ scores \\
\hline Control class & 20 & 45 & 85 & 60.75 & 13 \\
Experimental class & 20 & 45 & 80 & 61.00 & 14 \\
\hline
\end{tabular}

Fig.5 Scores Statistics of Post-test of Level-based Class Band One

According to the tables above, we can see that there are no remarkable differences between the result of the scores statistics of the control class and the experimental class, so we can conclude that before taking different teaching methods, there is no significant difference between students' English proficiencies of the two classes. Under such condition, the experimental study could be conducted.

However, for the students of the experimental class of group B, they did not feel the obvious effectiveness of the schema-oriented teaching method in their reading classes. Because of their comparatively low English proficiency, the vocabulary and grammar knowledge mastered by them is limited. They felt there were difficulties for them to remember so many new words and understand a lot of the sentences of the text, let alone to guess the intention of the author and so on. So, they believed their first task should be to enlarge their vocabulary and to consolidate the foundation of 
their grammar knowledge. They believe the schema-oriented teaching method can only be well used with a good English foundation. On the other hand, for the students of the control class of group B, they felt though their reading classes in college are no more interest than those in their high school, they enlarged their vocabulary and made the foundation of their grammar knowledge solid little by little. So they felt the traditional teaching methods, though a little boring, are helpful for them.

Schema-oriented teaching methods can help students to develop a good reading habit and to grasp a lot of useful reading strategies and skills. Under the guidance of schema theory, teachers may assign different tasks such as searching for the background knowledge, group discussion, practicing the predicting ability, analyzing the structure, question answering, summarizing and role play in different stages of reading. These activities actually have laid a solid foundation for the students to develop a good reading habit and gradually affect them to make use of these techniques by themselves when reading new materials.

There should be systematic and various reading ability assessments. Students' reading ability should not only be assessed by how much vocabulary they can remember, how many sentences they can translate appropriately or how many multiple choices exercises they can finish correctly. By using the schema-oriented teaching method, we can select any activities such as summary writing, presentation, role-play, discussion and so on to check students' reading achievement. Teachers should observe students' performance through these activities to record their progress in English reading rather than only based on the test papers.

\section{Conclusions}

The main purposes of this study were to examine the effects of the application of schema theory in college English reading teaching on improving students' reading comprehension. The results of the research suggest that although there is remarkable difference in the results of group A. So the conclusion can be drawn that the application of schema theory in college English reading teaching can help students, especially those students with comparatively high English proficiency, to activate the related schemata in their brain, which can affect students' English acquisition and reading comprehension. These findings will provide suggestions for practical college English teaching.

\section{Acknowledgements}

This paper is one of the results in the research project which name is "An Empirical Study on the A pplication of Formal Schema Theory to EFL Writing in the University"(Jiangxi foreign language teaching research project,2013). The project number is $13 \mathrm{WX} 330$.

\section{References}

[1] Aebersold, J. A.\&M. L. From reader to reading teacher. New York Cambridge University Press, 1997

[2] Anderson, R. C.,\&Pearson, P. D. A schema theory view of basic processes in reading comprehension. In P. Pearson (Ed.), Handbook of reading research. New York \&London Longman. 1984.

[3] Ammon, M.S. Patterns of performance among bilingual Children who score low in reading. In S.R. Goldman\&H.T. Trueba (Eds.). Becoming literate in English as a second language. Norwood, NJ: Ablex,1987:71-105.

[4] Goodman, K.S. An Interactive Approach to second Language Reading. Beijing: World Publishing Corporation, 1997.

[5] LT.Union, Internet reports 2005: The Internet of things-executive summary, 2005, Available: http://www.itu.int/publ/S-POL-IR.IT 2005/e 